\title{
Tianjin Time Machine
}

\author{
Aurélia Desplain $^{\mathrm{a} *}$, Davide Gherdevich ${ }^{\mathrm{b}}$ \\ ${ }^{a}$ UMR 8173 Chine Corée Japon, Centre d'études sur la Chine moderne et contemporaine, aurelia.desplain@ehess.fr \\ ${ }^{b}$ Université Paris-Saclay, UVSQ, DYPAC,davide.gherdevich@uvsq.fr \\ * Corresponding author
}

Keywords: Geohistorical data, Historical GIS, Anthropology, 3D GIS, Historical maps, urbanism, History

\begin{abstract}
:
The Tianjin Time Machine project is an interdisciplinary project in social anthropology, contemporary history, geomatics and information and communication sciences. The project aims at creating an on-line platform for a virtual tour of parts of the former French concession of the municipality of Tianjin (China), beginning with the buildings built by the Crédit Foncier d'Extrême-Orient (1907-1056) in this concession.

The municipality of Tianjin, which current population exceeds 15 millions, intends to become the country's third largest metropolis and a model of Chinese modernity. Tianjin has long been an international strategic city. Indeed, Tianjin became a "treaty port" at the end of the Second Opium War (1856-1860), and then it gradually opened its territory to nine foreign concessions: English, French, American, German, Japanese, Russian, Italian, Austrian and Belgian. The history of these concessions as well as their architectural heritage are now fully part of the (re)construction of the identity of Tianjin. The processes of modernisation of the city, significantly accelerated since the 2000s, generate major tensions between the logics of urban renovation and that of preserving a rich architectural heritage and/or promoting it for its high tourist potential.
\end{abstract}

The project aims to revive places in the former French concession (some heritage sites, others that have disappeared) in order to explore the questions raised by the articulation of these tensions. Based on the little-known archives of Crédit Foncier d'Extrême-Orient, it will bring together various sources (iconographic, textual, sound) to offer an immersive virtual visit on an online platform making media collections available, integrating the spatio-temporal dimensions and 3D digitisation of a prestigious building.

The project is based on the archive of the Crédit Foncier d'Extrême-Orient (1907-1956), kept at the Belgium State Archives in Brussels. It is an extremely rich fund containing, for each building, letters, property management documents, names of tenants, architectural plans etc. It is accompanied by a rich collection of photographs showing a large part of the buildings in Tianjin during the period of the French concession.

This material, in particular the iconographic apparatus, will be included in a WebGIS, in which various historical maps of Tianjin from the time of the French concession in 1860 to 1955 will also be visible. The maps have been georeferenced regressively from the current data available map and backwards to the oldest map. This is due to the fact that the enormous urban changes in the city over the years have completely changed the existing urban layout at the time of the concessions. The cadastral plans of the French concession in Tianjin, available for the years 1918 and 1926 , and the plan of the buildings of the Crédit Foncier d'Extrême-Orient, all kept at the French Diplomatic archives in Nantes (France), will be restored and digitised. Then we will georeference and vectorize this cartographic base. The names of the owners of the individual plots of land is mentioned on the 1918 and 1926 cadastral plans. It will allow us to analyse the evolution of the properties over a short but significant period of time ( 8 years). The various plans of the buildings of the Crédit Foncier d'Extrême-Orient, from the different archives collections mentioned, allows us to geolocate the individual buildings and the photos kept in the Brussels archive.

The last part of the project, which will end in June 2022, will be the creation of a 3D Web GIS, in which the reproductions of some key buildings of the French concession will be enhanced.

References: 
Brion, René, et Jean-Louis Moreau. 2001. « Inventaire des archives du Crédit Foncier d'Extrême-Orient et de sa filiale, la Société Hypothécaire de Tanger: 1907-1991 ». Les archives de l’État en Belgique. BE-A0545 / I 300.

Chabaille, Fleur. 2015. «La concession française de Tianjin: une histoire connectée de l'expansion des concessions étrangères en Chine (1846-1946) ». Thèse de doctorat, Lyon 2.

Coomans, Thomas, et Leung-kwok Prudence Lau. 2012. «Les tribulations d'un architecte belge en Chine: Gustave Volckaert, au service du Crédit Foncier d'Extrême-Orient, 1914-1954 ». Revue belge d'archéologie et d'histoire de l'art 81: 129-53.

Gabbiani, Luca, éd. 2016. Urban life in China, 15th-20th centuries: communities, institutions, representations. Paris: École française d'Extrême-Orient.

Mengin, Christine. 2014. «Écrire l'histoire des concessions de Tianjin par l'architecture : état des lieux ». Outre-Mers. Revue d'histoire 101 (382): 13-25.

Noizet, Hélène, Boris Bove, et Laurent Costa. 2013. Paris de parcelles en pixels: analyse géomatique de l'espace parisien médiéval et moderne. Saint Denis (Seine-Saint-Denis), France: Presses universitaires de Vincennes.

Singaravélou, Pierre. 2017. Tianjin cosmopolis: une autre histoire de la mondialisation. Paris: Seuil.

Thireau, Isabelle. (sous presse). Des lieux en commun. Une ethnographie des rassemblements publics en Chine contemporaine. Paris: Éditions de l'EHESS.

Figure 1. Tianjin Time Machine WebGIS

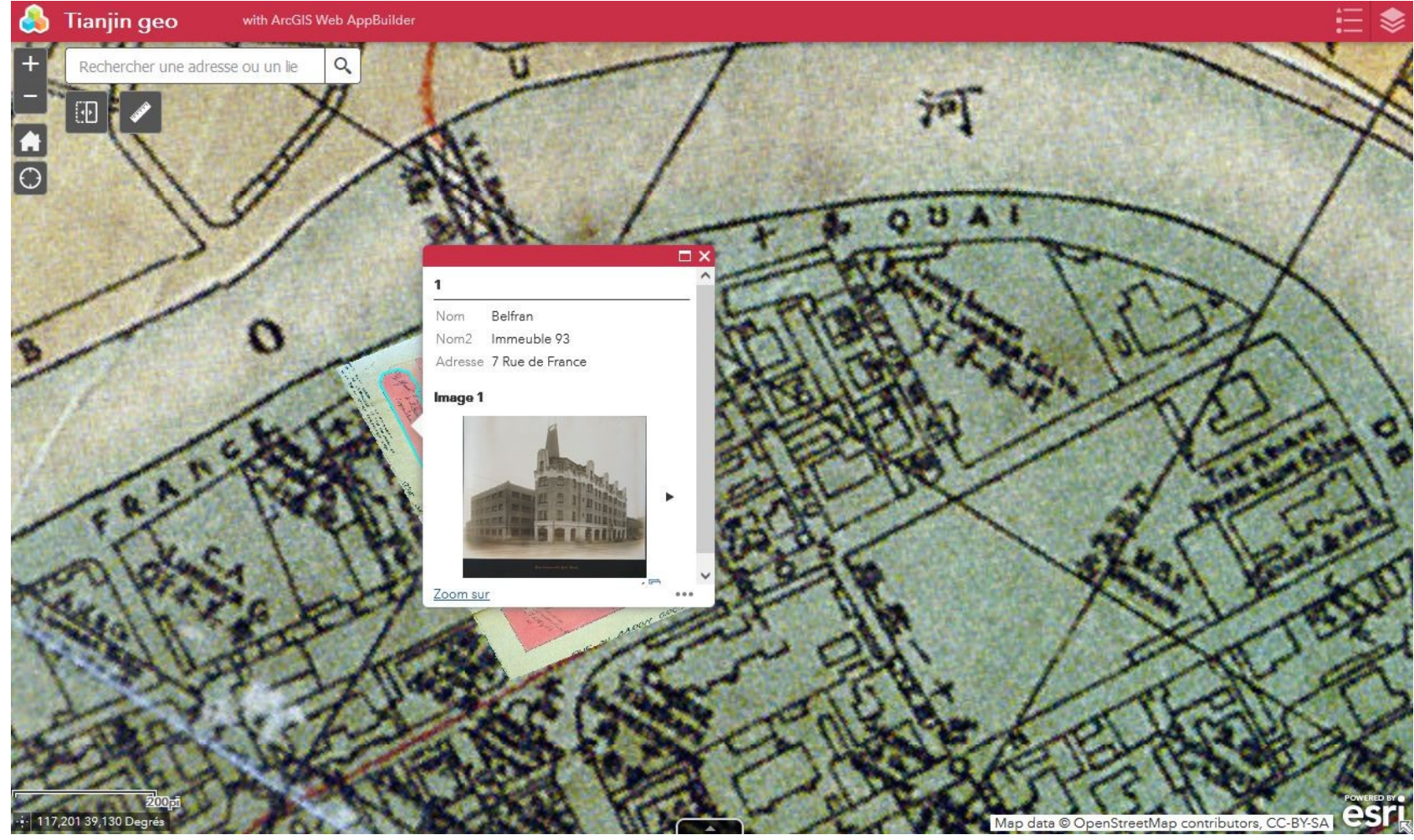

